\title{
PONTUAÇÃO: UMA QUESTÃO PROSÓDICA, SINTÁTICA, DISCURSIVA E SEMÂNTICA
}

\author{
PUNCTUATION: A PROSODIC, SYNTACTIC, DISCOURSIVE AND SEMANTIC ISSUE
}

\author{
Valéria Campos MUNIZ \\ Instituto Nacional de Educação de Surdos- DESU \\ valcammuniz@gmail.com
}

\begin{abstract}
Resumo: Este trabalho tem por objetivo discutir a pontuação como partícipe da organização do texto, não só em sua dimensão sintática, conferindo-lhe inteligibilidade, como também na dimensão enunciativa, revelando traços de subjetividade, permitindo ao autor satisfazer suas intenções discursivas. Para tanto, foram analisados textos jornalísticos e textos literários, com o respaldo teórico-metodológico da Gramática, da Linguística do Texto e da Estilística, em uma perspectiva enunciativa-discursiva, a fim de perceber como determinados sentidos se instauram, preenchendo uma expectativa discursiva, no âmbito sintático, mas com expressão também na prosódia, com repercussões na semântica. Essa plurifuncionalidade dos sinais permite ao autor conquistar efeitos de sentidos, antes só alcançados por intermédio da oralidade. $O$ sistema pontuatório, portanto, ao representar pausas (ou ausência delas), confere ao texto certa cadência (entoação, ritmo, linha melódica), que contribui para a significação da frase, atingindo a estrutura interna do texto, que, por vezes, denuncia aspectos enunciativos paralelamente às palavras. Assim, pretendeu-se, neste trabalho, analisar os sentidos provenientes do uso de diferentes sinais de pontuação em contextos diversos, a fim de comprovar que a significação se encontra na confluência dessas funções, submetendo-se o sistema pontuatório a todas elas, e não apenas à sintaxe, em conformidade com a circunstância comunicativa, numa espécie de completude.
\end{abstract}

Palavras-chave: Pontuação. Sintaxe. Prosódia. Discurso.

Abstract: This paper aims to discuss the role of punctuation in the organization of the text, not only in its syntactic dimension, conferring intelligibility, but also in the enunciative dimension, revealing traces of subjectivity, and allowing the author to satisfy his discursive intentions. For that, we analysed journalistic and literary texts, with the theoretical-methodological support of Grammar, Textual Linguistics and Stylistics, in an enunciative-discursive perspective, in order to perceive how certain meanings are established, fulfilling a discursive expectation, in the syntactic context, but with expression also in the prosody, with repercussions in the semantics. This multifunctionality of the signs allows the author to built effects of meaning, previously only reached through orality. The punctuation system, therefore, in representing pauses (or absence of them), gives the text a certain cadence (intonation, rhythm, melodic line), which contributes to the meaning of the phrase, reaching the internal structure of the 
text, which sometimes denounces enunciative aspects parallel to words. Thus, the aim of this study was to analyze the meanings produced by the use of different punctuation marks in different contexts, in order to prove that the significance lies at the confluence of these functions, subjecting the scoring system to all of them, and not only to the syntax, according to the communicative circumstance, in a kind of completeness.

Keywords: punctuation, syntax, prosody, speech

\section{Introdução}

A história da pontuação está entrelaçada à da evolução da escrita. Conforme Mattos e Silva (1993, p.76), de uma escrita contínua, passou-se aos espaços em branco entre as palavras, como fonte delimitadora, para depois, se chegar à inserção dos sinais gráficos, sendo o ponto, o primeiro deles.

Foi um processo gradativo, paralelo ao desenvolvimento da organização do texto escrito, ainda disseminado oralmente. Como a leitura que se processava em voz alta, a pontuação tinha a função primária de indicar pausas que ocorriam na fala, ou seja, estava relacionada às pausas respiratórias. Havia uma tentativa de transpor para a escrita a sonoridade da frase da língua falada, com sua entoação. Assim, paulatinamente, a função dos sinais passa a se desvincular da oralidade, da arte de declamar, para se fundamentar em princípios lógico-gramaticais. Isso nunca significou, todavia, o rompimento do vínculo dialógico entre escrita e oralidade.

Nos primórdios de sua criação, o uso dos sinais não tinha uma relação com a gramática como hoje. Podiam aparecer "pontos" em lugares considerados irregulares do ponto de vista da gramática normativa atual, mas perfeitamente normais para a época em questão. Dessa forma, a segmentação do texto em blocos, em porções de sentido, encontrava-se na dependência do critério prosódico.

Ao realizar um levantamento das definições de pontuação, em diferentes gramáticas no período entre 1831 e 2010 - Francisco Solano, Júlio Ribeiro, Maximino Maciel, Mario Pereira, Eduardo Carlos Pereira, Celso Cunha e Lindley Cintra, Rocha Lima e José Carlos de Azeredo -, percebemos que a 
natureza dos sinais de pontuação tem sua motivação na prosódia, sintaxe e discurso, estando fortemente relacionada ao sentido, à lógica do texto, ao separar palavras e proposições. Embora alguns gramáticos deem mais proeminência a uns aspectos do que a outros, não há verdadeiramente um distanciamento entre eles.

Os estudos sobre pontuação refletem sua plurifuncionalidade e, entre suas funções, algumas são consideradas de mais forte relevância que outras, sem haver opinião consensual entre estudiosos. Ao destacarem a entoação e o aspecto rítmico, associam o sistema pontuatório à fala, mas, de maneira geral, ressalta-se o fato de a representarem de forma "imperfeita". Quando o sentido, porém, é enfatizado, a inteligibilidade se mostra a característica mais importante dos sinais, conforme observamos nas frases: (1) "Ela caminhava pela rua silenciosa", (2) "Ela caminhava pela rua, silenciosa", em que a vírgula é responsável pelo significado. É a pontuação, por exemplo, que determina a forma de leitura das frases:

- "Ele já chegou." (curva melódica descendente)

- "Ele já chegou?" (curva melódica ascendente)

Sob uma perspectiva funcional, tanto a pontuação quanto a entoação respondem pelo aspecto significativo das frases, havendo entre as duas correspondência ou assimetria, dependendo do tipo de sinal. Desse modo, para ilustrar, um ponto indicativo de pausa conclusa demanda a realização de uma pausa, proferida de forma mais ou menos longa, dependendo do leitor; a vírgula, entretanto, nem sempre será demarcada. No último caso, a pausa, realizada, ainda mantém vínculo bastante estreito com respiração; não sendo o único fator decisivo para sua efetivação, uma vez que também está sujeita ao gosto pessoal do leitor. Já um sinal como o ponto de interrogação, por exemplo, exige leitura ascendente. Quando a pergunta é longa e o sinal encontra-se distante, muitas vezes o leitor é obrigado a retornar à leitura, a fim de refazer a entonação da frase, de modo a imprimir-lhe sentido adequado. A leitura das aspas, significando ironia, difícil de ser modulada, obriga aquele que 
lê em voz alta para uma plateia a indicar de alguma forma esta intenção, seja por intermédio de gesto ou de explicitação.

De modo geral, os sinais apresentam correspondente prosódico, fazem transparecer a intenção subjacente de marcar a modulação da leitura, representando a inflexão da voz, mas mesmo um sinal como a vírgula, por exemplo, com relevante função na organização do texto, nem sempre interfere no modo de ler um texto. O ritmo da leitura dependerá do leitor, havendo sinais que, em razão desse ritmo, não correspondem a pausas, bem como pausas não representadas na escrita. Não há dúvida de que um texto lido com as inflexões de suas pausas permite ao ouvinte organizar informações, enquanto que uma leitura rápida, mesmo com as palavras bem pronunciadas, dependendo das interferências externas, pode dificultar a compreensão, captando o ouvinte apenas alguns fragmentos.

Há textos em que a pontuação delimita uma interferência do narrador, firmando uma aproximação do leitor, ao transparecer sua opinião acerca do tema em questão: "O que por agora importa saber é que Virgília - chamava-se Virgília - entrou na alcova (...)" (ASSIS, 1994, p.12); "E depois - cogitações de enfermo - dado que chegássemos ao fim indicado (...)" (idem, p.15). Os sinais têm papel primordial, ao estabelecer interação entre narrador e leitor, instituindo uma intimidade. Sua leitura deve-se realizar com uma modulação diferente, de modo que o ouvinte perceba a presença dessa opinião, diferenciando-a da trama narrativa. Situações do tipo, muito frequente nos textos de Machado, demarcam dois atos de fala distintos, produzidos pelo mesmo enunciatário. $O$ fragmento sinalizado pela pontuação denota uma apreciação acerca do que está dito no contexto enunciativo. No exemplo a seguir, retirado do jornal, da seção "Dos leitores", embora não haja um diálogo com o leitor, o autor deixa transparecer sua indignação não só por intermédio da exclamação, como pelo próprio advérbio, que, ao ser colocado entre travessões, transparece "uma voz interior" que se sobrepõe à do próprio ato de fala da carta: "O andamento do processo proposto contra os mensaleiros 
depende do voto do ministro relator, o esforçado Joaquim Barbosa, o qual não consegue - nunca! - concluir seu voto" (O Globo, 15/12/2011, p.8).

Assim como os travessões, o parêntese, nos fragmentos, desempenha igual função: (1) "Onde estaria ele na hora do crime? (Será que devo dizer?)"; (2) "Entregou o governo com uma inflação mensal (é mensal mesmo, leitor), em março de 1990, de 84\%" (O Globo, 29/11/11, p.6). O aspecto prosódico da pontuação, nos exemplos, também exige que a leitura dos segmentos intercalados seja feita com uma entoação diferenciada.

Como signos enunciativos, tais sinais - vírgula, parêntese, travessão -, apesar de utilizados em um mesmo contexto, têm objetivos distintos; em situações em que configuram dois atos de fala de um mesmo enunciador ou em circunstâncias polifônicas, para haver o destaque da voz do enunciador, verifica-se frequência absoluta dos dois últimos. Catach (1980, p. 22) aponta a dupla vírgula também com função enunciativa, afirmando que por muito tempo a vírgula junto com o ponto bastava para introduzir o discurso direto ou uma citação. Nos casos, a voz do outro está explícita. Acreditamos que a preferência por sinais como parêntese e travessão, na mídia impressa atual, ocorra em razão de a vírgula não demarcar a voz do autor ou não fazer transparecer o trecho em que a opinião do autor se torna mais explícita, como no exemplo acima, retirado do jornal O Globo "- nunca! -".

Como a vírgula tem outros usos, ela se perde nessa função, enquanto os outros dois sinais favorecem a inteligibilidade do texto. Um caso que contraria o que está prescrito na gramática normativa, sem prejudicar a compreensão, é o uso da vírgula para delimitar as diferentes vozes no texto abaixo de José Saramago:

\footnotetext{
Mal sentado, porque a cadeira de palhinha era muito mais baixa que o trono, o rei estava a procurar a melhor maneira de acomodar as pernas, ora encolhendo-as ora estendendo-as para os lados, enquanto o homem que queria um barco esperava com paciência a pergunta que se seguiria, E tu para que queres um barco, pode-se saber, foi o que o rei de facto perguntou, com sofrível comodidade, na cadeira da mulher da limpeza, Para ir à procura da ilha desconhecida, respondeu o homem, Que ilha desconhecida, perguntou o rei disfarçando o riso (...) (SARAMAGO, 1998 , p. 16, grifos nossos).
} 
No trecho, as falas do diálogo foram sinalizadas pelo uso da maiúscula, sem indicação de aspas ou itálico. Tampouco houve marcação por intermédio dos dois pontos, sinal característico do discurso direto, mas pela vírgula. $O$ ponto e o ponto de interrogação também foram substituídos pela vírgula. $\mathrm{O}$ autor violou as regras de pontuação, mas não comprometeu a compreensão, uma vez que as estruturas frasais são recuperáveis. Ou seja, no trecho, o diálogo não está marcado por recurso gráfico, pontuação ou mudança de linha, mas pelos verbos dicendi, que não deixam de marcar "com precisão e colorido, a atitude da personagem cuja fala vai ser textualmente reproduzida" (CUNHA \& CINTRA, 1985, p. 619). Os verbos desempenham a função de indicar a mudança de interlocutor, da mesma forma que a pontuação, cuja atuação se revela suplementar, redundante, o que possibilita a troca entre os sinais.

Apesar de o texto contrariar a prática comum no uso dos sinais em diálogo, o leitor, ao se acostumar com a pontuação, realiza todas as pausas indicativas dos sinais pontuatórios propostas pela gramática para as situações de diálogo, com suas entoações, necessitando, quando muito, talvez, de uma segunda leitura, já que, na primeira, tende a ler de modo mais ou menos corrido. Tal característica da escrita de Saramago configura a marca de seu estilo e, aparentemente, sem grandes funções discursivas.

O que Saramago faz é admissível porque se trata do domínio discursivo literário, no qual a liberdade é maior que no jornalístico, no burocrático, no técnico etc. O importante, entretanto, no texto literário, é o autor explorar os recursos que a língua oferece e perceber, se assim o desejar, o modo de fugir ao lugar-comum.

Já no indireto livre, há um cuidado em não demarcar o discurso polifônico por intermédio da pontuação, dificultando intencionalmente a percepção do leitor. Observemos: 
Seu Tomé da bolandeira falava bem, estragava os olhos em cima de jornais e livros, mas não sabia mandar: pedia. Esquisitice de um homem remediado ser cortês. Até o povo censurava aquelas maneiras. Mas todos obedeciam a ele. Ah! Quem disse que não obedeciam? (Grifo nosso, RAMOS, 1977, p.22)

A pontuação, contudo, não deixa claro a quem pertence a voz, ao narrador, ou ao personagem? Talvez por isso discursos ambíguos como esse tenham ficado restritos praticamente ao domínio discursivo literário.

Agindo de modo normativo, pode o autor indicar, para demarcar a intercalação de elementos longos, o travessão ou o parêntese; se curto, a vírgula ou um dos anteriores (caso haja uma intenção subjacente de destacar ou fornecer uma informação a mais, respectivamente). Caso a sequência contenha em seu interior uma ou mais vírgulas, o melhor a se utilizar é o parêntese ou o travessão, pois a vírgula não destacaria o constituinte intercalado. Não há regras fixas, já que situações diversas podem contrariar o que se propõe aqui.

Atualmente, na mídia impressa, por exemplo, observamos que, enquanto o travessão se presta ao destaque de informações, o parêntese tem sido bastante utilizado em situações de identificação de valores, siglas, pessoas e lugares, além de servir como indicador de termos explicativos: "O conceito de que os valores defendidos (capitalismo e democracia) são universais e exportáveis..." ( $O$ Globo, 27/11/11, p.6). Diferentemente, no texto literário, pode o autor explorar as regras, infringindo, muitas vezes, o prescrito pela gramática normativa de modo a obter efeito estilístico. Assim, verificamos pelas palavras de Mário de Andrade a seu amigo Manuel Bandeira:

\footnotetext{
Examina a pontuação que adotei atualmente. O mínimo de vírgulas possível. A vírgula a maior parte das vezes, sabes, é preconceito de gramático. Uso dela só quando sua ausência prejudica a clareza do discurso, ou como descanso rítmico expressivo. Também abandonei a pontuação em certos lugares onde as frases se amontoam polifônicas (apud OLIVEIRA, 1999, p.42).

O texto jornalístico e o literário são sempre boas fontes de consulta, servindo como objeto de estudo de outras formas de pontuação que rompem
} 
com a construção canônica, desvelando a pontuação como um dos recursos discursivos a serviço do objetivo do autor.

Retomando à questão da relação entre discurso oral e pontuação, muitas pessoas, ao pontuarem um texto, guiam-se pela sonoridade da língua, utilizando o aspecto prosódico como norteador da escrita, em vez do critério gramatical. Isso acarreta, às vezes, pontuações inadequadas, como o uso de vírgula entre o predicado e o sujeito, quando este é longo, prática que, aliás, gramáticas antigas toleravam. De acordo com Câmara Jr, "a apresentação do vocábulo na escrita se faz pelo critério formal" (1978, p.69), ou seja, os limites das palavras são definidos pelos espaços em branco deixados entre elas. Todavia, na cadeia sonora, como não existe marca que indique tal limitação, muitos segmentos são proferidos num único grupo prosódico, o que faz, por exemplo, com que crianças, em início do aprendizado da língua escrita, escrevam-nos como uma única palavra: <acasa> <depaulo>. Neste grupo prosódico (ou grupo de força, segundo Mattoso), há dois vocábulos fonológicos, redigidos como duas palavras, em virtude de o monossílabo átono apoiar-se na tonicidade da palavra seguinte. Fatos assim são causa de vários erros de ortografia: "porisso", "derrepente", "medeu" etc. Outro exemplo (entre muitos): alguns usuários da língua escrita têm o hábito de sistematicamente usar vírgula depois da conjunção que integrante, o que faz suspeitar que na fala façam pausa nesse contexto, talvez a serviço da ênfase, o que não significa que tais pausas existam em todas as regiões de língua portuguesa, em todas as faixas etárias, grupos profissionais etc. Uma pontuação baseada, portanto, apenas no aspecto prosódico da língua seria excessivamente complexa e, se pensarmos pedagogicamente, inviável!

Por vezes, é possível identificar tentativas de exprimir na escrita aspectos emotivos da comunicação oral, nem sempre fáceis de transposição para o papel, a qual não conta com recursos, como gestos, olhares, sutilezas entoacionais etc. Para tanto, o recurso utilizado é a combinação ou repetição de sinais - !!?, ?! , ??? etc. - reveladores da tentativa de sugerir sentidos que 
ultrapassem as palavras. Há que se ressaltar, no entanto, não serem esses aspectos prosódicos aceitáveis na prosa formal não literária.

Ao enfocarmos a relação entre pontuação e oralidade, levamos em consideração a diferença entre a leitura em voz alta e a fala distensa, ato de linguagem do cotidiano. A prosódia entre os dois atos de linguagem é diferente, uma vez que as pessoas não leem como falam. Ao ler em voz alta, o leitor tem na sintaxe da frase e nos sinais uma espécie de guia para o ritmo do texto, com reflexos na leitura, mais acelerada ou pausada, em virtude de regras que admitem facultatividade. Deverá, portanto, o leitor conhecer a funcionalidade dos sinais de pontuação, a fim de apreender os sentidos das linhas e das entrelinhas. Por outro lado, um texto sem qualquer sinal de pontuação tenderá a se segmentar conforme a prosódia da língua falada e, por não haver justa simetria entre as duas modalidades, a leitura se dará entre idas e vindas, num ato custoso de reestabelecimento de sentido.

O modo como um texto é lido influencia diretamente seu ouvinte, na medida em que um texto lido sem pausas, de forma monocórdia, além de prejudicar o entendimento, muitas vezes, faz com que a atenção se dilua. Em casos de tradução simultânea, por exemplo, em que o tradutor deve obedecer ao ritmo do palestrante, o ouvinte pode sentir dificuldade em construir sentido, dependendo do conteúdo da palestra, mesmo com a fala em sua própria língua.

Em outras situações, como diálogo ou fala de improviso, as pausas se realizam sem que exista um cuidado prévio e consciente de sua demarcação. Neste tipo de código, quem toma a palavra tem sempre a possibilidade de reformular o enunciado, de modo a desfazer um mal entendido e atingir seu objetivo. As pausas, portanto, se inadequadas, ajustam-se em tempo real. É um ato de linguagem repleto de hesitações, repetições, redundância, em que as pausas estão diretamente relacionadas ao estado emocional do locutor e à própria situação de fala. O código oral e o escrito, por se constituírem em diferentes recursos de expressão, regem-se por regras próprias, que se 
traduzem em diferenças de sentido, embora haja a projeção de um no outro em determinados momentos, pelo fato de a pontuação estar na área de confluência entre a prosódia e a sintaxe.

Percebemos a projeção quando redigimos. Ao fazermos a autocorreção, muitas vezes, recorremos a aspectos suprassegmentais presentes na leitura em voz alta, a fim de, por intermédio da sonoridade da frase - ritmo, entoação, linha melódica - percebermos a harmonia do texto e apararmos as arestas da imperfeição. A escuta existe também internamente, conforme Chafe (1987, p. 397), e quanto mais experiente o redator, melhor a percepção dos aspectos. Essa maturidade revela-se crucial nos casos de topicalização. Se considerarmos que o escritor, no ato de redigir, é também um ouvinte, que "escuta" uma voz interior que the "fala" e the permite experimentar uma "imagem auditiva" dos ritmos, acentos e pausas, ele poderá inadvertidamente inserir sinal de pontuação onde não existe. A escuta pode induzi-lo a realizações pontuatórias inadequadas, que traduzem formas pessoais de leitura, como o caso, já ilustrado, da vírgula entre o sujeito e o predicado. Como a escrita é um ato ao mesmo tempo de reescritura, o autor, atento às possíveis armadilhas de sua voz interior, saberá como evitá-las ou corrigi-las. Podemos afirmar, então, que a pontuação, em certa medida, é um retrato da escuta do autor (idem, p. 396).

Se compararmos o aspecto prosódico da leitura em voz alta com a pontuação de um texto, verificaremos que há momentos em que eles coincidem ou não, o que ocorre porque a construção da forma escrita e a da oral são diferentes. Há casos em que o excesso de vírgulas, por exemplo, rompe a cadência da frase, em outros, a ausência de pontuação obriga ao leitor realizar pausas para tornar a leitura mais confortável. De acordo com Chafe (1988), o falante tende a proferir blocos entoativos com mesma unidade de extensão, o que reafirma a funcionalidade dos sinais de pontuação como sinalizadores da leitura e não uma "camisa de força". Apesar de o autor centrar seu estudo na língua inglesa, acreditamos que seu comentário valha também 
para o português, podendo, talvez, ser considerado até certo ponto universal. Quando a leitura é silenciosa, a possibilidade de a entoação coincidir com as pausas realizadas na escrita é maior, pois o leitor tem mais tempo para processar a informação do que quando se exige que leia em voz alta.

Em outras palavras, a relação entre prosódia e pontuação não é biunívoca, o que fica ainda mais claro se considerarmos o sistema pontuatório inerente a todas as línguas que utilizam o alfabeto latino (GLEASON, apud ROSA, 1994, p. 26). No caso, não podemos falar da medida exata relativa à sua prosódia, uma vez que cada uma delas tem um ritmo frasal que the é peculiar. É perfeitamente plausível uma variação no que diz respeito às regras de uso, pois a pontuação se sujeita às características próprias de cada língua. Mesmo assim, grande parte das regras vale para todos ou quase todos os idiomas que utilizam tal alfabeto, o que as caracteriza, até certo ponto, como universais.

A diferenciação entre pontuação e fala também se identifica em textos de épocas distintas, em estilos diversos. No português atual, pode-se verificar - na prosa de ficção e em alguns gêneros textuais por ela influenciados - uma predileção por frases curtas, coordenadas. As orações complexas dão lugar às simples, para realçar determinadas sequências discursivas, recurso impensável numa pontuação mais tradicional. Essa maneira mais hodierna de pontuar contrasta com o estilo "caudaloso" da ficção de outras épocas, de estrutura frequentemente subordinativa, "característica marcante do classicismo e de certa fase do romantismo" (GARCIA, 1995, p. 105). Nota-se que a inovação no uso dos sinais chega à sintaxe da frase, caracterizando um novo estilo, em que concisão e clareza acompanham a rapidez da informação, significando economia de tempo. A pontuação, portanto, também segue, assim como a própria estrutura da língua, as tendências de época.

É precisamente por existirem diferentes ritmos de fala que se torna inevitável, na gramática escolar, por exemplo, incluir regras facultativas de pontuação (OLIVEIRA, 2010), o que se dá em razão de sua essência 
plurifuncional. Muitas vezes, a regra não é facultativa, mas o tipo de contexto, mídia impressa, por exemplo, em nome de uma "clareza visual", pode "infringila", sem que isso seja condenado, como o caso do uso da vírgula na indicação de adjuntos adverbiais deslocados: "Mas nos últimos anos tem havido uma crescente politização da ajuda humanitária..." (O Globo, 1/12/11, p.37). Conforme a gramática, é facultativo colocar o adjunto adverbial entre vírgulas e, quando deslocado para o meio ou o início da frase, a vírgula é aconselhável, sobretudo se ele for longo (os conceitos de "longo" e "curto" ficam por conta da intuição de quem escreve): "Nas ruas do país, a notícia foi acolhida com uma mistura de alegria..." (O Globo, 1/12/11, p. 37).

Há situações em que, dependendo da intenção comunicativa, mais de um sinal pode ser utilizado numa mesma situação enunciativa, como:

a) ponto e vírgula no lugar da vírgula: "- Não - respondeu ele estremecendo -; não; admiro o esplendor da noite. Veja; está celestial!" (ASSIS, 1994, p.34).

b) ponto no lugar da vírgula: "Naturalmente haveria que se providenciar o estuda das condições de adequação do aeródromo para uso civil, com os investimentos para tanto necessários. Mas certamente valeria a pena" (O Globo, 1/12/11, p.7).

c) ponto e vírgula no lugar dos dois-pontos: "Entro na primeira loja que tinha à mão; era um cubículo - pouco mais - empoeirado e escuro" (ASSIS, 1994, p.53).

Existe também a possibilidade de se omitir uma conjunção em prol de um sinal de pontuação:

a) dois-pontos em vez da conjunção causal: "O capitão perguntou-me se tivera medo, se estivera em risco, se não achara sublime o espetáculo: tudo isso com um interesse de amigo" (ASSIS, 1994, p.35).

b) ou, mais raramente, ponto e vírgula em vez de conjunção causal: "Renunciei tudo; tinha o espírito atônito" (ASSIS, 1994, p.42). 
Enfim, cada situação, de modo particular, definirá o sinal utilizado, resultando dessa escolha nuances de significado, assim como, há outras em que é indiferente sua utilização, caso do vocativo utilizado nas cartas empresariais, em que se admitem vírgula, dois pontos, ponto, ou até mesmo nada (CUNHA e CINTRA, 1985, p. 637).

A pontuação é, por assim dizer, uma das responsáveis pela estruturação do texto, situa-se no entremeio da organização das informações advindas do pensamento, e da própria circunstância comunicativa - o contexto. É, consequentemente, fator de planejamento do processo da escritura, revelando, à semelhança dos modalizadores, posições do escritor, favorecendo a reflexão de seu leitor. Conforme Chafe (1988, p. 399), um dos grandes méritos de um escritor experiente é transferir para seu texto a entoação de unidades da língua oral por intermédio da pontuação.

Apesar da forte motivação prosódica do sistema pontuatório, algumas regras da gramática são convencionais, embora com uma justificativa sintática. Em relação à vírgula, por exemplo, entre os casos "proibitivos", há a prescrição de não a inserir entre o sujeito e o predicado, entre o verbo e o complemento, entre o objeto direto e indireto.

Observamos, todavia, que pausa separando os dois constituintes básicos da oração - sintagma nominal sujeito e sintagma verbal (predicado) -, embora incorreta para a gramática normativa, não causa estranhamento, haja vista os inúmeros casos de vírgula entre sujeito e predicado, principalmente em redações escolares, em virtude das topicalizações que aquele sofre, índice de que o aluno intui a existência de tal pausa na fala, o que evidentemente não justifica a vírgula.

Já pausas entre o verbo e o complemento, direto, indireto, relativo, circunstancial ou "complemento do predicado" (PERINI, 2007, p.82), são improváveis: "O João emprestou $\downarrow$ o livro à Alice", "Eu obedeço $\downarrow$ ao chefe", "Raul gosta $\downarrow$ de futebol", "Maria mora $\downarrow$ no Ceará", "O Rio de Janeiro é $\downarrow$ a cidade maravilhosa" (nestes exemplos, o símbolo " $\downarrow$ ” indica pausa improvável; 
tudo leva a crer que, quando ocorre, trata-se do tipo de pausa que o falante faz às vezes para pensar o que vai dizer e que costuma ser preenchida por fillers (OLIVEIRA, 2005).

Não se justifica, portanto, admitir a vírgula num contexto em que a pausa só é possível em condições tão alheias à língua escrita. Já entre o sujeito e o predicado, como vimos, bem como entre o objeto direto e o indireto, ocorrem pausas na fala em circunstâncias "normais", como em "O João $\downarrow$ emprestou o livro $\downarrow$ à Alice" (o símbolo " $\downarrow$ " desta vez significa pausa "normal” facultativa). No caso, a gramática (acertadamente) opta por uma solução convencional, interditando o emprego da vírgula em contextos nos quais a pausa "normal" é possível.

A pausa entre o objeto direto e o indireto se explicaria em razão de este situar-se numa área de confluência entre termo integrante e acessório, de ser "mais acessório que o objeto direto e mais integrante que o adjunto adverbial" (OLIVEIRA, 2010). Aliás, há muito em comum entre o objeto indireto e o adjunto adverbial, inclusive a possibilidade de fazer pausa entre ele e seus "vizinhos".

Decorrente do modo de apreender os sinais, verifica-se que as regras "proibitivas" não recebem o mesmo tratamento na gramática, que dá o mesmo peso às três "proibições". Em se tratando de ensino da pontuação, didaticamente, há situações em que tratar questões de língua de forma binária é mais fácil para o aluno assimilar as noções envolvidas. Como explicar a existência de graus prosódicos em relação a essas pausas? Dentro de tal ordem de ideias, o ensino escolar interdita igualmente a vírgula nas três situações. Seria pedagogicamente indesejável falar em graus de interdição.

Embora o ensino da sintaxe, e da gramática como um todo, tenha sido "combatido" com variados argumentos, durante muitos anos, como objeto de estudo nas salas de aula, não há dúvida de que seu conhecimento embasa a criação de diversos tipos de construção frasal. Se pensarmos que a pontuação situa-se na interseção da prosódia, sintaxe, semântica e discurso, a sintaxe, 
devido a sua própria natureza constitutiva de regras, dessas áreas, é a opção que, ao mesmo tempo que define, descarta criações que contrariem a lógica da língua. Às vezes, trechos mal pontuados ou com pontuação inusitada exigem do leitor incômodas idas e vindas. Apesar da proeminência sintática, reforçamos a necessidade da inclusão de conceitos discursivos e semânticos na descrição da língua, que se encontram presentes mesmo que de forma subjacente. A língua existe para significar conteúdos, logo a semântica está presente em todas as situações de sua utilização, a serviço de alguma função da linguagem, não necessariamente a de comunicar. $O$ aspecto discursivo, portanto, fica onipresente (OLIVEIRA, 2007).

A área de confluência, da qual o sistema pontuatório é integrante, faz com que estudiosos do assunto ora destaquem uma função em detrimento de outra. Os estudos, todavia, não se devem analisar de forma excludente. De modo geral, há certo consenso em torno de a função primordial da pontuação facilitar a leitura e contribuir para a compreensão do texto. Esta, segundo Dahlet (1995, p. 339), até poderia ser seu aspecto básico, se a escrita significasse expressão do pensamento, isto é, o discurso pertenceria ao sujeito e os sinais gráficos consistiriam num fato de língua, a serviço da clareza do pensamento. No caso, ler estaria circunscrito a decodificar, na medida em que o texto apresentaria apenas um sentido. A pontuação, portanto, teria papel de mero acessório, 0 que garantiria a transmissão da mensagem. Se considerarmos a língua como instrumento de comunicação e o sujeito determinado pelo sistema $(\mathrm{KOCH}$, 2002, p. 17), o texto se configurará como produto codificado, cabendo ao leitor também uma atuação passiva, uma vez que, com acesso ao código linguístico, sua tarefa se limitaria a decifrá-lo. Se pensarmos, entretanto, a pontuação como partícipe do ato enunciativo, podem seus sinais submeter-se a todas as funções, sem regularidade de apenas uma delas, sem que se conceba plenitude de uma única função. Valores prosódicos, estilísticos, sintáticos e semânticos harmonizam-se em torno de um objetivo único, o texto. 
Se escrever é inscrever-se como enunciador, o sentido do texto não estaria neste ou naquele ponto, mas na soma de todos, numa espécie de completude, fazendo do texto um tecido, em que nenhum fio pode estar solto, sob pena de sua descaracterização. Na medida em que a escrita requer organização do pensamento, está a pontuação - em alguns momentos mais que em outros - associada à sintaxe e/ou à prosódia, podendo também subordinar-se às necessidades discursivas do enunciador, submetendo-se às circunstâncias do discurso, à relação contratual, aos efeitos de sentido almejados.

Os sinais de pontuação, vistos como constituintes da cadeia gráfica, não podem ser considerados elementos acessórios, como talvez pareça ao leigo, pois compõem sentido junto às letras. Ao funcionarem como elemento de continuidade na elaboração das ideias, exercem papel estruturante do pensamento, indispensável na ordenação das palavras. Se analisarmos os sinais de pontuação também como signos linguísticos, que à maneira das palavras instrumentais têm caráter contínuo e não pontual, não há como menosprezá-los em função dos outros signos, na medida em que singularizam linguisticamente as unidades na cadeia discursiva. Um texto sem tais caracteres resultaria num emaranhado de palavras, até legível, mas sua leitura seria custosa, quando não impraticável. Tão importante quanto a escolha lexical e o uso de conectivos, na construção do texto escrito, é o papel dos sinais de pontuação que, além da função demarcativa, oferecem a possibilidade ao usuário de optar por um deles em detrimento de outros, dependendo das circunstâncias.

Vista sob essa ótica, a pontuação, ao lado de outras funções, constitui-se marcador gráfico da enunciação; ficando na interseção entre a prosódia, a sintaxe, os estudos do discurso e a semântica, que, direta ou indiretamente, está presente em todos os níveis da análise linguística: onde houver linguagem haverá significação. 
Como "nossa gramática 'mental' contém regras que correlacionam a hierarquia das pausas com as fronteiras sintáticas" (OLIVEIRA, 2005, p. 82-83), é interessante recorrer a conceitos morfossintáticos na formulação das regras para o emprego desses sinais, sobretudo da vírgula.

Exemplos (para citar apenas três):

(1) De modo geral não há pausa entre o artigo e o substantivo, daí ser inconcebível algo como "o, livro", “a, mesa”, "os, pássaros" etc., mesmo que entre os dois haja um filler; num caso assim, o que se poderia usar na escrita seriam talvez as reticências: "o... livro", "a... mesa", "os... pássaros.

(2) O aposto explicativo fica entre pausas - daí ficar entre vírgulas na escrita.

(3) O vocativo também fica entre pausas - daí as vírgulas.

O aspecto discursivo da pontuação decorre, portanto, do fato de que todo texto é produzido numa situação comunicativa concreta, o que leva alguns sinais a adquirirem valores discursivos. É o caso: (1) dos dois-pontos, que anunciam o que vem depois, tendo, portanto, valor catafórico; (2) das reticências, a serviço do suspense; (3) das variadas emoções que exprimimos com o ponto de exclamação, às vezes combinado, como já se disse, com o de interrogação (!, !!, !!!, !?); (4) do ponto de interrogação em função interrogativa ou interacional, com pergunta retórica. E assim por diante...

Desse modo, a pontuação pode adquirir, entre outros valores, o afetivo, ou expressivo, permitindo ao usuário da língua a realização de suas intenções estéticas, tornando possível ir além da face intelectiva da linguagem, principalmente na prosa literária, como observamos em Saramago (1998), em que o autor dispensa os dois-pontos ou as aspas para marcar as falas, empregando apenas uma pontuação de palavra, a maiúscula.

Apesar da existência de regras que normatizam a pontuação, o contexto enunciativo, conforme já visto, influenciará de forma decisiva na organização do texto, isto é, as regras poderão flexibilizar-se em prol da expressividade e 
das exigências de cada gênero textual. É bom esclarecer que os preceitos da gramática referentes à pontuação se aplicam, tipicamente, à prosa formal não literária. Na poesia atual, em textos publicitários e mesmo na prosa de ficção hodierna, ou não se aplicam, ou sofrem adaptações (OLIVEIRA, 2010).

Um dos traços comuns à pontuação na publicidade é a "economia" de vírgulas. Entre os profissionais existe o conceito de que as vírgulas "sujam" o texto, "o poluem" visualmente. Os publicitários explicitam o que poetas e ficcionistas fazem sem explicitar ou explicitam esporadicamente, mas não com um discurso unânime como o deles. Em tais gêneros, vírgulas, pontos e doispontos tendem a limitar-se aos indispensáveis. Ponto e vírgula, nem pensar. Até pode ocorrer, mas como um verdadeiro apatriado.

Na prosa de ficção, observa-se ainda - opcionalmente - a obediência à pontuação canônica, que, no gênero, é um pouco mais aceitável que na poesia ou no anúncio. Afinal é prosa, ainda que de ficção. O habitat natural das regras é a prosa formal não literária. No conjunto de gêneros textuais, a pontuação apresenta um comportamento que justifica sua descrição em base predominantemente sintática, com algumas aberturas para prosódia e para o discurso. No parágrafo, "Sinais de fumaça. Telegramas. Código Morse. Telefone. Rádio. Telefone. Celular. Computador. Internet. Bluetooth. O mundo gira, a roda muda e os meios de comunicação avançam, atropelam e são atropelados.", escrito por um aluno, houve a opção pelo ponto em vez de vírgula, de uso regular. Com certa cronologia, o aluno enumera o avanço nos meios de comunicação, fornecendo maior destaque ao utilizar o ponto que, nem por isso, demanda uma leitura com a pausa que lhe é devida. Pode o leitor ler o trecho como se os pontos fossem vírgulas, mas, apesar de no aspecto prosódico ser quase indiferente, estilisticamente se percebe no ponto a ênfase dada à criação de cada tipo de tecnologia. Indo além, o ponto denuncia o tempo para o surgimento de cada um. Então, esse tipo de pontuação, trazido da prosa de ficção, revela que as fronteiras entre os gêneros não são tão fixas. A prosa não literária incorpora, às vezes, inovações surgidas no texto literário. 
Um exemplo de obra ficcional pontuada de modo pouco ortodoxo é a de José Saramago, conforme vimos, mas ele não é o único. Há, na literatura de ficção da atualidade, uma tendência à pontuação com economia de vírgulas. Sem elas, o texto flui melhor. A tendência não se restringe às literaturas de língua portuguesa. Veja-se a respeito o fragmento de À l'abri de rien, de Olivier Adam (manteve-se a pontuação do original):

(...) todas essas coisas espalhadas por lá tinham de ser arrumadas mais cedo ou mais tarde, o pacote de cereais rasgado os garfos as facas as colheres, os biscoitos a garrafa de leite e no salão os brinquedos as revistas os quebra-cabeças, a latinha de cerveja o saca-rolhas o cinzeiro cheio 0 cobertor o pacote de lenços (...) (ADAM, 2007, p. 53).

(...) toutes ces choses qui traînaient et qu'il faudrait ranger à un moment ou à un autre, le paquet de céréales éventré les fourchettes les couteaux les cuillers, les biscuits la bouteille de lait et au salon les jouets les magazines les puzzles, la cannette de bière le tire-bouchon le cendrier plein la couverturee le paquet de mouchouir.(...) (ADAM, 2007, p. 53).

Pela regra que se conhece, separam-se com vírgulas os itens de uma enumeração. A personagem-narradora, no entanto, os agrupou em blocos e limitou-se a colocar vírgulas entre os blocos, o que permite a interpretação de que se trataria de uma pontuação icônica: o desânimo de arrumar a casa se teria manifestado no texto sob a forma de "preguiça" de pontuar.

O texto literário, por sua natureza estética, é muitas vezes fonte de inovações estilísticas que posteriormente se incorporam a outros domínios discursivos. Por isso, mesmo em pesquisa cujo foco sejam discursos não literários, há interesse em observá-las.

O aspecto subjetivo da produção textual está ligado ao processo criativo da escrita, o qual é uma atividade que exige planejamento, envolve escolhas e decisões. Perguntas como "o que se pretende escrever?", "de que forma?" são importantes, pois definem estratégias que apontam para o objetivo almejado. $\mathrm{O}$ escritor, ao redigir, precisa atentar às suas idéias e à disposição e hierarquização delas no texto, além de perceber que a maneira como pretende organizá-las não é indiferente. A leitura de um texto, por sua vez, envolve entender o que significam as palavras no interior de determinado contexto, com 
as necessárias ligações, a fim de permitir concepção coerente do objeto lido. Como afirma Charaudeau (2008, p. 26), "não se pode determinar de forma apriorística o paradigma do signo, já que é o ato de linguagem, em sua totalidade discursiva, que o constitui a cada momento de forma específica”. O sistema pontuatório, por fazer parte da organização do texto escrito, atua lado a lado com as palavras e, de modo singular, aos conectivos, complementando o sentido, possibilitando integração leitor/texto.

Estabelecer a importância do texto como unidade de linguagem em uso, manifesta em determinada circunstância, implica salientar sua característica básica - unidade semântica, veiculadora de significado. A pontuação, enquanto partícipe da estruturação compósita, compartilha tanto da coesão quanto da coerência.

Um fator que contribui para a coerência na constituição do texto são os mecanismos coesivos responsáveis pelas relações de sentido entre suas partes. A pontuação, como um desses elementos, sinaliza para os nexos que se processarão, recuperados pelo leitor no momento da interação. Há casos em que se dispensam os conectivos, sendo a coerência estabelecida de forma linear e pluridimensional, como em: "Joana acordou cedo. Sua mãe preparou o café. Ela precisa chegar cedo à escola. Haverá prova de matemática no primeiro tempo."

Em outro caso, "Manhã, banho, café, ônibus, trabalho, obrigações, almoço, obrigações, ufa!, ônibus, casa, noite, banho, janta, televisão, cama!!!” (Exemplo nosso), em que temos uma enumeração, a pontuação, aliada ao campo semântico, ordena hierarquicamente as palavras, favorecendo sua unidade. De maneira geral, afirma-se que o texto não apresenta elementos de coesão, pois consideram apenas os conectivos como responsáveis pelo processo. Para nós, entretanto, existe coesão, que se estabelece por intermédio da pontuação de forma complementar ao arranjo das palavras.

\section{Considerações finais}


Os efeitos literários provenientes do uso dos sinais de pontuação representam exímio material para se explorarem aspectos enunciativos e discursivos, como também para aprofundar questões sintáticas, dirimindo dúvidas decorrentes do exercício da escrita. Embora o discurso configure material farto para se observar flutuações na pontuação, o contexto é, ao mesmo tempo, fomentador e limitador das criações do escritor, pois as submete à dinâmica estrutural da língua. Ou seja, a escolha dos sinais de pontuação somente atinge plena dimensão enunciativa no interior do discurso, quando tem seu significado revelado na associação ao signo linguístico.

Desse modo, perceber que, de uma pluralidade significativa, determinados sentidos se instauram, preenchendo uma expectativa discursiva, é trabalhar a utilização dos sinais na dimensão da estruturação do texto, no âmbito sintático, com expressão na prosódia, no discurso e na semântica.

Conforme Charaudeau (2008), cada texto está submetido às "regras" de um "contrato de comunicação" e às "circunstâncias do discurso", não sendo o ambiente material suficiente em si mesmo. Os gêneros são imbuídos de características que nos levam a apreender sua função. Em um jornal, esperamse encontrar notícias verídicas, enquanto num texto ficcional não existe tal expectativa. Perceber isso é dar-se conta das diferentes possibilidades de pontuar, uma vez que como vimos a pontuação de uma notícia pode não ser exatamente igual a da literatura de ficção.

Afora casos específicos, a significação alcançada pela pontuação em conjunto com outros elementos presentes no texto ultrapassa o quesito de mera propriedade do texto. Visto sob uma concepção interacional da linguagem, o sentido do sistema pontuatório será "construído na interação texto-sujeitos, que mobilizam seu contexto sociocognitivo, constituindo uma configuração veiculadora de sentidos" $(\mathrm{KOCH}, 2002$, p. 17). Aprender a lidar com a língua escrita, portanto, implica aprender a colocar em consonância a sintaxe, a prosódia e o discurso, de modo a que interpretações prosódicas se realizem sobre padrões sintáticos específicos. 


\section{Referências bibliográficas}

ASSIS, J. M. M. de. Memórias póstumas de Brás Cubas. São Paulo: Scipione, 1994.

AZEREDO, J. C. de. Gramática Houaiss da língua portuguesa. 2. ed. São Paulo: Publifolha, 2008.

CÂMARA JR., J. M. Contribuição à estilística portuguesa. 3. ed. Rio de Janeiro: Ao livro técnico, 1978.

CATACH, N. La ponctuation. In: LANGUE Française. n. 45, 1980. p. 16-27.

CHAFE, W. What good is punctuation. Occasional paper n.2, 1987. Disponível em: < http://www.eric.ed.gov/PDFS/ED292120.pdf >. Acesso em: 8 ago. 2011.

CHARAUDEAU, P.; MAINGUENEAU, D. Dicionário de análise do discurso. 2. ed. São Paulo: Contexto, 2008.

CONSTANCIO D. M., Francisco Solano. Grammatica analytica da língua portugueza. Paris: Officina Typographica de Casimir, 1831.

CUNHA, C. F. da; CINTRA, L. F. L. Nova gramática do português contemporâneo. 2. ed. Rio de Janeiro: Nova Fronteira, 1985.

DAHLET, V. Pontuação, língua, discurso. In: SEMINÁRIO DO GEL, 24., 1995, São Paulo. Anais: estudos linguisticos.

GARCIA, O. M. Comunicação em prosa moderna. 16. ed. Rio de Janeiro: Fundação Getúlio Vargas, 1995.

$\mathrm{KOCH}$, I. G. V. Desvendando os segredos do texto. 2. ed. São Paulo: Cortez, 2002.

LIMA, C. H. da R. Gramática normativa da língua portuguesa. 31. ed. Rio de Janeiro: José Olympio, 1992.

LIMA, M. P. de S. Gramática expositiva da língua portuguesa. São Paulo: Companhia Editora Nacional, 1937.

MAINGUENEAU, D. Análise de textos de comunicação. São Paulo: Cortez, 2004. 
MACIEL, M. Grammatica descriptiva. 3. milheiro da 6. ed. Rio de Janeiro: Francisco Alves \& Cia, 1916.

MATTOS E SILVA, R. V. O que nos diz sobre a sintaxe a pontuação de manuscritos medievais portugueses. ABRALIN, São Paulo, n. 14, p. 75-85, 1993.

OLIVEIRA, H. F. de. Como e quando interferir no comportamento linguístico do aluno. In: JÚDICE, N., GAVAZZI, S., TROUCHE, L. et al (Org.). Português em debate. Niterói: Editora da Universidade Federal Fluminense, 1999. p. 65-82.

Como tornar as teorias sobre a linguagem aplicáveis ao ensino de português? Comunicação apresentada no Congresso Nacional de Linguística e Filologia. UERJ, 2005.

. Gêneros textuais e conceitos afins: teoria. In: VALENTE, André (Org). Língua portuguesa e identidade: marcas culturais. Rio de Janeiro: Caetés, 2007.

. Curso ministrado no Doutorado em Língua Portuguesa, UERJ, $1^{\circ}$ semestre de 2010.

ORLANDI, E. P. Língua e conhecimento lingüístico: para uma história das idéias no Brasil. São Paulo: Cortez, 2002. A linguagem e seu funcionamento: as formas do discurso. 4. ed. São Paulo, 2001.

PEREIRA, E. C. Gramatica Expositiva: curso superior. 58. ed. São Paulo: Companhia Editora Nacional,1942. [a primeira edição é de 1907.]

PERINI, M. Gramática descritiva do português. São Paulo: Ática, 2007.

RAMOS, G. Vidas secas. 72. ed. Rio de Janeiro: Record, 1997.

RIBEIRO, J. Grammatica portugueza. 2. ed. São Paulo: Teixeira \& Irmão, Editores, 1885.

ROSA, M. C. A. P. Pontuação e sintaxe em impressos portugueses renascentistas. 1994. 281f. Tese (Doutorado) - Universidade Federal do Rio de Janeiro.

SARAMAGO, J. O conto da ilha desconhecida. 27a reimpressão. São Paulo: Companhia das letras, 1998. 